\title{
IMPERSONAL PASSIVES IN ICELANDIC ${ }^{1}$
}

This paper argues that Icelandic impersonal passives have a constructional property that expresses generic events. After having demonstrated their basic characteristics, it is shown that the notion of 'activity' is inadequate for the explanation of why the construction is licensed. The behaviour of the adverbial sér meðvitandi is diagnosed to show indefiniteness tied up with the construction.

\section{Introduction}

Impersonal passives are highly productive grammatical constructions in modern Icelandic. They typically appear with a past participle form of intransitive as well as transitive verbs, often containing an expletive $b a ð$ 'it, there' at the initial position of a sentence. ${ }^{2}$

(1) Баð var synt.

it was swum

'There was swimming'

(2) Раð var skrifað.

it was written

'People wrote'

This construction is called impersonal because, syntactically speaking, it does not have a nominal governed by the base verb (see Klaiman 1991: 6, 8). The construction has received much attention in the literature of syntax and semantics particularly on Germanic languages such as Dutch and German (e.g. Perlmutter 1978; Kathol 1994; Pollard 1994; Zaenen 1993). In Icelandic too some research, though less extensively, has been put forward by several scholars (Zaenen and Maling 1990; Smith 1993; Van Valin 1991). A common idea in the previous discussion is that the applicability of impersonal passives is accounted for by means of the lexical property of a base verb. Following Perlmutter's original distinction between unergative and unaccusative, it is stated that impersonal passives are formed by unergative verbs, those verbs that are lexically characterized as having an external argument and, hence, an agentive subject.

After it became obvious that the 'Unaccusative Hypothesis' does not hold up well in many languages (e.g. Levin and Rappaport 1989), researchers paid close attention

1 I would like to thank Magnús Pétursson who provided me with the data and took the time to discuss tricky areas of the Icelandic impersonal passive. Without his help and generosity this paper would not have taken this form. I thank Peter Sells who read an earlier version of this paper and made helpful suggestions. Errors are exclusively mine.

2 In this paper we mainly deal with intransitive verbs and treat transitive verbs only marginally. The exact treatment of this construction with transitives is beyond the scope of this paper (see footnote 5). 
to impersonal passives on the basis of different semantic criteria. Dowty (1991:607ff) appeals to the idea of bifurcation of intransitive verbs by considering the semantic element 'volition' as a salient component of agentivity; the presence or absence of volition for the triggering of the action determines the classification of intransitive verbs. Preserving the notions, agentive verbs come to be considered unergative, while nonagentive verbs are considered unaccusative. Thus, the ungrammaticality of the sentence in (3) is explained by the fact that sökkva 'sink' is an unaccusative verb in that volition is definitely not a relevant factor for an entity such as a ship to sink.

(3) * pað var sokkið.

it was sunk

'Sinking took place'

In contrast to (3), the reason that (1) is grammatical is that the activity of swimming necessarily involves volition or, more precisely, the swimmer has a will to do it; hence, synda is classified as unergative. In effect, Perlmutter's original proposal finds expression in Dowty in that verbs which undergo impersonal passivisation are felicitous with an agentive or volitional interpretation. As shown in (4), the impersonal passive in Dutch arises from an unaccusative verb stinken 'stink' only when the agent's volition is emphasised in such a way that the woman is interpreted as intentionally exuding the bad odours (example cited from Zaenen 1993: 139, (37); cited as well in Levin and Rappaport Hovav 1987).

(4) Er werd door de krengen gestonken.

'There is a stink from the nasty woman'

Although Zaenen (1993: 136) admits the presence of the component of volition in Dutch, she further argues (ibid 138) that the whole construction of impersonal passive encodes atelicity that is not determined by the lexical property of the verb. According to her, the acceptability of the impersonal passive ultimately depends on the aspect of the sentence as a whole but not purely on the lexical property of the base verb. As exemplified by the contrast in (5) and (6), the Dutch verb lopen 'run' is only compatible with impersonal passive when it is atelic, whereby the element of volition apparently plays no relevant role (examples cited from Zaenen 1993: 138, (32) and (33)).

(5) Er werd gelopen.

'There is running'

(6) *Er werd naar huis gelopen.

'There is running home'

In this paper, I will present an analysis of Icelandic impersonal passives that diverges in many respects from Dutch. Although for some researchers the unergative/unaccusative distinction is taken for granted in Icelandic (see Smith 1993, for 
example), ${ }^{3}$ Icelandic does not provide sufficient syntactic grounds for this statement (Yamaguchi in press). It does not, as will be discussed below, exhibit semantic unaccusativity either. Neither does aspect play a relevant role.

It will be shown that Icelandic impersonal passives are sensitive not merely to the lexical semantics of the base verb but also to the existence of the impersonal passive construction that expresses a 'generic event', an event that people or the members of a given circumstance generally take part in. ${ }^{4}$ Impersonal passives in Icelandic do not allow an adverbial expression sér meðvitandi 'consciously, be aware of', for this adverbial assigns the component of definiteness to the sentence. This mismatch is selfexplanatory in that generic events do not describe specific or individual, hence, definite episodes with which the meaning of this adverbial might be felicitous. The reason volition or aspect does not play a part in Icelandic is that these components are, in effect, insensitive to the notion of (in)definiteness.

The organisation of the paper is as follows. In section 2, I demonstrate some basic facts relevant to our ongoing discussion. In section 3, I review critically Van Valin's (1991) analysis that approaches Icelandic impersonal passives from a different semantic perspective. I argue that his proposal that the semantic primitive 'activity' is a decisive factor in the formation of Icelandic impersonal passives is not on the right track. In section 3, I show how my proposal can explicitly account for the applicability of impersonal passives in Icelandic. Finally in section 4, while summing up the findings, I refer to remaining problems which cannot be fully understood by the present proposal.

\section{Some Basic Facts}

\subsection{Expletive $p a \delta$}

As briefly referred to at the outset of this paper, Icelandic impersonal passives are formed by an expletive or a placeholder pað followed by an auxiliary vera 'be' and a past participle of the verb. Note that this past participle is always in a neuter and singular form. As illustrated in (7)b and (7)c, pad does not appear in the sentence, thereby the past participle remains neuter and singular and there is no change in meaning among these variants. ${ }^{5}$

3 Smith (1993: 480-481) states that verbs such as koma 'come', fara upp 'go up', fara ofan 'go down' liða 'pass' are unaccusative verbs with a theme subject just like sökkva 'sink', hence not forming impersonal passives. However, he is wrong in this statement because these verbs are uncontroversially good in impersonal passives; the themehood of subject cannot thus be a criterion for unaccusativity.

4 I follow the general idea presented in the versions of Construction Grammar that grammatical constructions represent pairings of form and meaning that are present independently of the base verbs occuring in them (e.g. Goldberg 1995, Kay and Fillmore 1999). However, the detailed theoretical criticism of the nature of grammatical constructions is beyond the scope of the paper.

5 In Icelandic some transitive verbs appear in the expletive construction. There are two types. The first type is shown in (i) where the passive form of the verb skrifa 'write' agrees with the noun bcekur 'books' in gender 


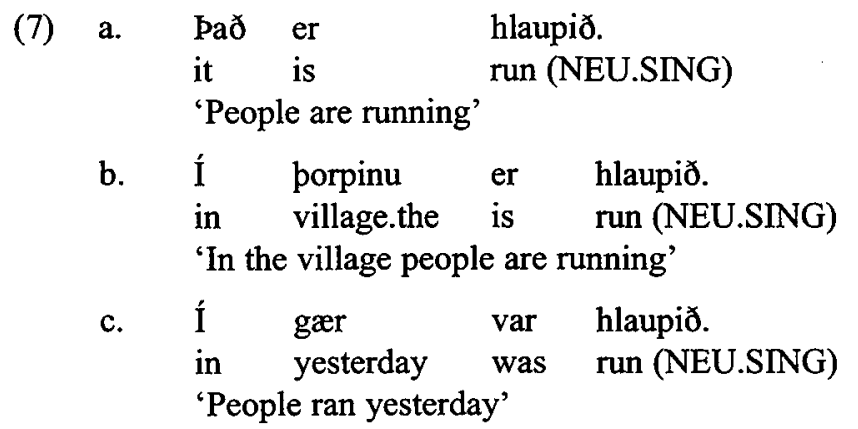

\section{2. $A f$-phrase}

In Icelandic the agent is expressed by the phrase headed by a preposition $a f^{\text {' }}$ by' in both passive constructions. In the personal passive construction the active agent is defocused and can appear in the af phrase, as in (8). ${ }^{6}$ By contrast, impersonal passives do not usually express the agent in the af phrase, as in (9). As indicated by (10), however, impersonal passives can allow the af phrase only when the agent refers to people in general or a collective number of people or things. In many studies in the past the subject of the active sentence is considered to be suppressed, defocused, or demoted structurally to give rise to the passive alternant (cf. Comrie 1977; Shibatani 1985). Examples below represent a case that impersonal passivisation cannot be explained fully by reference to this type of theoretical consideration, but it is shown to involve much more subtle aspects which are, in effect, semantic in nature. In descriptive terms, Icelandic impersonal passives function as 'impersonalisation' of a participant in the

and number. The agent can appear in the af phrase, as in personal passives in (ii), but it does not necessarily do so in a particular context in which the speaker puts more emphasis on the generic nature of the activity of writing, which cannot hold for personal passives.

(i) pað̆ enu skrifað̆ar bækur (?af mörgum stúdentum). it are written (FEM.PL) books (FEM.PL) (by many students) 'There are activities of writing of books by many students'
(ii) pessar bækur eru skrifaðar (af mörgum stúdentum). these books (FEM.PL) are written (FEM.PL) (by many students)
'These books are written by many students'

The second type is that, as exemplified by (iii), skrifa appears with the expletive $p a \delta$ without an implicit object, whereby the passive form of the verb does not exhibit agreement, being always in neuter and singular, just like impersonal passives with intransitives. The sentence expresses a 'generic event' (see section 4.1 for the term) and disallows the af phrase.
(iii) $\mathrm{Pa}$ er skrifað
it is written (NEU.SING) by John
'Someone wrote'

It appears that the expletive constructions with transitive verbs of the first type might be said to lie somewhere between personal passives and impersonal passives in morphosyntactic and semantic terms, and the second type is almost identical with impersonal passives with intransitives.

The term 'defocused' here refers to the mention of an agent in a non-prominent way in the sentence. 
designated event. Because of this semantics, only the agents who are not specified in that event are able to appear in the passive, as indicated by $(10)^{7}$.

(8) Dansinn var dansađur (af Maríu).

dance was danced (by Maria)

'The dance was danced by Maria'

(9) Pað var dansað (*af Maríu).

it was danced (by Maria)

'There was dancing'

(10) Pað er dokað við (*af Jóni/af peim/af fólkinu).

it is stayed (by John/by them/by people)

'People stayed'

\subsection{Aspect}

We noted that Dutch impersonal passives are sensitive to atelic aspect (section 1). However, I will show here that Icelandic impersonal passives are insensitive to aspect; they are available with or without the directional phrase. ${ }^{8}$

(11)

a. Pað er flutt.

it is moved

'People are moving'

b. Pað er flutt til Íslands.

it is moved to Iceland

'People are moving to Iceland'

(12) a. pað er komið.

it is come

'People are coming'

b. Рað er komið til hússins.

it is come to house.the

'People are coming home'

7 As I will mention in section 4, there are verbs which do not accept an overt expression of an af-phrase at all, for which I do not have an explanation at present.

8 German behaves, in some aspects, more similarly to Dutch. The verb ankommen 'arrive' is not compatible with impersonal passives when it co-occurs with a directional phrase, as exemplified by (i) and (ii) .

(i) Es wurde angekommen. (attested)

it was arrived

'There was an arrival'

(ii) *Es wurde angekommen nach Hause.

it was arrived to house

'There was an arrival to the house' 
In Yamaguchi (2000), it is claimed that the availability of the auxiliary vera 'be' is sensitive to the component of directionality if it exhibits a perfective reading, i.e. verbs such as flakka 'wander' take vera only when a direction is overtly expressed. However, impersonal passives differ significantly from perfective auxiliary constructions, as seen in (13), in that the selection of vera is not affected by directionality, as seen in (14). The different forms of past participles in (13) and (14) are due to the fact that they agree with subject in gender and number when they express perfectivity (section 2.1).

(13) Perfective:
a. *Hans er flakkaður.
Hans is wandered
b. Hans er flakkaður til stöðvarinnar. Hans is wandered (MASC.SING) to station.the

'Hans (is) wandered to the station (and he may be now at the station)'

(14) Impersonal Passive:
a. Рað er flakkað.
it is wandered (NEU.SING)
'People are wandering' it is wandered to station.the 'People are wandering to the station'
b. раð er flakkað til stöðvarinnar.

\subsection{Volition}

Volition can be expressed linguistically by adverbials such as, viljandi 'intentionally, knowingly', af ásettu ráði 'intentionally', or i peim tilgangi 'on purpose' in Icelandic. ${ }^{9}$ Although it is stated in terms of Dutch that verbs which co-occur with opzettelijk 'on purpose' are good in impersonal passives (Zaenen 1993: 133), Icelandic verbs cannot be subcategorised by this criterion. Consider verbs such as synda 'swim' and rilla 'roll' which behave in exactly the same manner with respect to these adverbials but they differ in terms of impersonal passivisation; the former permits it, while the latter does not.

$$
\begin{aligned}
& \text { a. Pað var synt. } \\
& \text { it was swum } \\
& \text { 'People swam' }
\end{aligned}
$$

9 It is in fact difficult to give exact English glosses which clearly distinguish between viljandi and af ásettu ráoi. Generally speaking, af ásettu ráði is more frequently used and expresses a stronger and established intention. A verb like fremja sjálfsmoró 'commit suicide' allows only the latter, because if one commits suicide, he/she has an established intention, i.e. that what he/she does is expected to lead him/her to death. 
b. Hans syndir viljandi.

af ásettu ráđi

í peim tilgangi

(16) a. *२að var rúllað.

it was rolled

b. Hans rúllaði viljandi.

af ásettu ráđi

í peim tilgangi

Verbs which behave analogously to synda and rúlla are listed below.

(17)

\begin{tabular}{|c|c|}
\hline synda & rúlla \\
\hline fara 'go' & birtast 'appear' \\
\hline ganga 'walk' & bogra 'crawl' \\
\hline hlaupa 'run' & deyfa 'make dim' \\
\hline hrópa 'cry' & hverfa 'disappear' \\
\hline kenna 'teach' & lykta 'smell' \\
\hline koma 'come' & vakna 'become awake' \\
\hline vaka 'be awake' & velta 'tumble' \\
\hline
\end{tabular}

The irrelevance of volitionality for the formation of impersonal passives in Icelandic is also obvious with respect to the verb lykta 'smell' whose behaviour is not influenced by the pragmatic context, as we noted with regard to example (4) above. Lykta does not form an impersonal passive under any circumstances.

(18) *pað er illa lyktað. it is badly smelt 'There is a stink'

\section{Van Valin (1991)}

Van Valin (1991) in his investigation of Icelandic verbs with Role and Reference Grammar (henceforth, $R R G$ ) framework claims that impersonal passives are available when verbs encode an activity predicate in their logical structure (ibid 190). He takes an adverb kröftuglega 'vigorously, energetically', which expresses an action, as a test to show the existence of activity as well as the applicability of impersonal passives in Icelandic. In this section I shall try to show by providing ample data that his semantic analysis, though interesting, is rather misleading.

According to him, there are two types of verbs which undergo impersonal passivisation; (i) verbs such as dansa 'dance', gráta 'cry', ferðast 'travel', hósta 'cough' 
which are in his RRG framework treated as activity verbs, and (ii) verbs such as koma 'come, arrive' which are motion accomplishment verbs, encoding both activity and achievement elements in their logical structure. Taking a verb like skjálfa 'shiver', which is an activity verb forming an impersonal passive, Van Valin states (ibid 190) that Icelandic verbs do not need a component of volition, as opposed to Perlmutter (1978) and Zaenen (1993), but need a single component of an action. In fact, this verb is only compatible with kröftuglega, as shown in (19), which supports Van Valin's claim at first sight.

(19) a. Barnið skalf kröftuglega/*viljandi $/ *^{*}$ af ásettu ráði $/{ }^{*}$ peim tilgangi. child shivered vigorously/intentionally/intentionally/on purpose 'The child shivered vigorously'

b. bað var skolfið.

it was shivered

'There was shivering'

However, one problem arises when we look at a near-synonymous verb titra 'shiver' which is compatible with kröftuglega and behaves almost similarly to skjálfa in active sentences, as in (20a), although it is bad in impersonal passive, as in (20b). We come to recognise that this contrasting behaviour of these two verbs can hardly back up Van Valin's claim.

(20) a. Barnið titraði kröftuglega/?viljandi/*af ásettu ráði ${ }^{*}{ }^{i}$ peim tilgangi. child shivered vigorously/intentionally 'The child shivered vigorously'

b. *pað var titrað.

it was shivered

'There was shivering'

One salient difference between skjálfa and titra is semantic. The activity of shivering encoded in skálfa is caused by natural phenomena like coldness due to a low temperature, for instance, whereas the shivering encoded in titra is caused by internal human conditions such as fear or excitement. The contrast in (21) illustrates the case in point; titra does not allow kulda 'coldness' as a causal element.
$\begin{array}{lll}\text { a. Barnið skalf } & \text { vegna kulda. } \\ \text { child shivered } & \text { because of coldness }\end{array}$
'The child shivered because of the coldness'
b. Barnið titraði vegna *kulda/af æsingu.
child shivered because of coldness/by excitement
'The child shivered/shook because of the coldness/excitement

Van Valin gives a further example for the legitimacy of the semantic relevance of activity. For instance, an expression vera heima 'stay/remain at home' permits an 
impersonal passive, as shown in (22), and this expression is to be an activity predicate in spite of the presence of the copula vera 'be', which signals, as a rule, the stativity of a predicate. He provides, for instance, a sentence like (23) as a diagnostic test for the validity of the activity component.

(22) Рað var mikið verið heima á kvöldin.

it was much been at.home in the.evening

'People remained home a lot in the evening'

(Van Valin 1991: 187, (58b))

(23) Fólk var ekki heima af ásettu ráoi á kvöldin.

people was not at home intentionally in the evening

'People intentionally did not remain at home in the evening'

(see Van Valin 1991: 188 (59a); slightly modified by the author)

Note, however, that (23) co-occurs with af ásettu rádi, being a signal for the presence of volition, but not for that of activity. It is striking that, as in (24), kröftuglega, being a signal for the presence of activity, is infelicitous and this empirical fact contradicts his own argument, i.e. that the compatibility of af ásettu rádi does indicate that impersonal passivisation is possible even though verbs are not necessarily classified as activity predicates.

(24) *Fólk var ekki heima kröftuglega á kvöldin. people was not at home vigorously in the evening

In fact, it appears that it is almost impossible to single out the activity component with respect to the availability of impersonal passives. First, there are weather verbs which disallow volitional components as modification but only allow an action component and, interestingly, they do not permit an impersonal passive at all. (26) lists other kinds of weather verbs which behave in exactly the same way.

(25) a. Pað rignir kröftuglega/*viljandi.

it rains vigorously/intentionally

'It is raining hard'

b. *bað er rignt.

it is rained

(26) blása 'blow', frjósa 'freeze', skína 'shine', snjóa 'snow', ...

One might argue that the inapplicability of impersonal passives is brought about by the inanimacy linked to the weather verbs. For instance, Van Valin claims (1991: 186) that the Icelandic impersonal construction "is restricted to intransitive verbs which take animate actors". However, there are passivisable verbs such as falla 'fall', fara 'go', gróa 'grow', koma 'come', sigla 'sail' which assign what he calls undergoer to their single argument. This is exemplified by the examples (27) and (28), where falla and 
sigla are compatible with animate and inanimate subjects and absolutely good in impersonal passive. That is to say, the sentence Pad var fallio in (27)b, for instance, can refer either to animate (e.g. an athlete) or inanimate entities (e.g. signposts on the street) which can fall. In this respect, it might not be correct to make a generalisation that impersonal passives in Icelandic are restricted to intransitives only with animate actors.

(27) a. Skiltið/ípróttamaðurinn fellur. signpost/athlete fell

'The signpost/athlete fell'

b. Pað var fallið.

it was fallen

'Falling took place'

(28) a. Maðurinn/Skipið sigldi.

Man/ship sailed

'The man/ship sailed'

b. Pað var siglt.

it was sailed

'There was sailing'

There are verbs apart from weather verbs that permit kröftuglega but do not form an impersonal passive. One such verb is detta 'fall'. Although it is a near synonym to falla, it does not permit an inanimate entity as subject. The reason is that the meaning of detta involves human motivation, i.e. actions conducted by humans, not necessarily intentional, which brings a fall about (e.g. a mistake by an athlete).

(29) a. Ípróttamaðurinn dettur kröftuglega. athlete fell vigorously

'The athlete fell vigorously'

b. * pað var dottið.

it was fallen

There are also verbs such as hvilast 'rest' which behave in a reversed manner; they permit an impersonal passive although they are not compatible with kröftuglega.

(30) a. *María hvíldist kröftuglega.

Maria rested vigorously

b. Pað var hvílst.

it was rested

'People rested'

It follows that the isolation of the component 'activity' is not a relevant criterion for the availability of impersonal passives contra Van Valin. A serious problem associated with his analysis might be that he deals with restricted data on which his theo- 
retical generalisations are built. Recall his generalisation that vera heima is an activity predicate ((22) and (23)). Although he refers to predicates in English which are formed with be to show their activity entailment, this idea cannot be extended straightforwardly to Icelandic, however. One of his activity be predicates is 'be a jerk' (1991: 187) whose Icelandic counterpart is vera heimskur. The behaviour of this verb cannot support his generalisation, as shown in (31); none of the adverbials are felicitous.

(31) Jón er *kröftuglega/*viljandi/*af ásettu ráði heimskur. Jón is vigorously/intentionally/intentionally a jerk

Although some be predicates, as listed in (32), are felicitous with af ásettu rádi 'intentionally', as seen in (33), they are still infelicitous with kröftuglega.

(32) vera hávar 'be noisy', vera pögull 'be quiet', vera ruddalegur 'be rude'

(33) Jón er *kröftuglega/?viljandi/af ásettu ráđi pögull/hávær/ruddalegur 'Jón is quiet/noisy/rude deliberately'

In addition, it is worthy of mention that what are generally called stative verbs such as vita 'know' and pekkja 'know' are uncontroversially good in impersonal passives. Their non-activity element can be shown by $a$ and $b$ examples in (34) and (35), i.e. they neither permit kröftuglega or viljandi nor pass a vera að test to diagnose the possibility of forming a progressive aspect.

(34) a. Jóa vissi *kröftuglega/*viljandi.

Jóa knew vigorously/intentionally

b. *Jóa var að vita.

Jóa was at know

'Jóa was knowing'

c. एаð var vitað.

it was known

'People knew'

(35) a. Pröstur pekkti *kröftuglega/*viljandi.

Pröstur knew vigorously/intentionally

b. *bröstur var að pekkja.

Pröstur was at know

'Pröstur was knowing'

c. Dað var pekkt.

it was known

'People knew'

If the stativity, which is treated as another primitive in $R R G$, should play a role, as Van Valin claims, the behaviour of vita and pekkja would be highly controversial. 
However, the data in (34) and (35) serve as good evidence for our present approach that the semantics that plays a role in the formation of impersonal passives in Icelandic extends beyond the distinction between stativity and activity. In sum, all these empirical facts demonstrated above make it explicit that the component 'activity' and the diagnostic tests used are not considered to be bona fides criteria and do not count even as a motivation for a unified account of Icelandic impersonal passives. In other words, it might be fair to say that the notion 'activity' should be treated rather as scaffolding, but not as a primitive, providing basic information such as 'the number of participants' or 'the global type of events'. In this aspect, Van Valin's statement "only intransitive verbs which have an activity predicate in their LS [...] can form impersonal passives" (1991: 189) turns out to be inappropriate.

\section{Proposal}

\subsection{Generic Event}

In section 1 I briefly mentioned that Icelandic impersonal passives express events which people generally take part in, and I dubbed this type of event 'generic event'. In the detailed discussion about the concept of genericity in Krifka et al. (1995) sentences such as John smokes a cigar after dinner or A potato contains vitamin C, amino acids, protein and thiamine are considered generic sentences, since they "do not express specific episodes or isolated facts, but instead report a kind of general property, that is, report a regularity which summarizes groups of particular episodes or facts" (ibid 2). In this paper, I do not go into the detailed analysis of genericity, but what I would like to do is to use the insights in Krifka et al that generic sentences do not report particular episodes or facts, but rather some kind of generalisation over events. This characterisation of genericity neatly fits into the semantics of impersonal passive sentences in Icelandic. As demonstrated in examples (36), the availability of adverbs almennt 'generally' and persónulega 'personally' indicates the fact that there is an essential semantic difference between impersonal passive and active sentences. In actives both adverbs are permitted, that is, specific participants as well as collective members of people can be allowed to appear, while in impersonal passives only almennt is felicitous. As I mentioned earlier (2.2), impersonal passives are not compatible with the of 'by' phrase if it refers to a particular individual such as Hans. This is shown in (36)c. Note, however, that the sentence becomes grammatical when Hans is replaced by a non-specific expression like people. All these empirical facts strengthen the legitimacy of the present assumption that Icelandic impersonal passives are nothing but generic sentences which express a kind of general property of events - the property in the sense that events can be participated in by people in general. So, (36) b and c below serve to report a regularity over a situation in which people were flying, while the speaker does not say who they were exactly. 
(36) a. Hans flaug almennt/persónulega.
Hans flew generally/personally
b. Баð var almennt/*persónulega flogið
it was generally/personally flown
c. pað var flogið (*af Hans/ af fólkinu).
it was flown (by Hans/by people)

Verbs forming impersonal passives are, in fact, large in number in Icelandic. The following two lists give a bird's eye view of the distribution of verbs that allow or disallow an impersonal passive. Although it is beyond the scope of this paper to answer the question of why verbs in (38) disallow the formation of impersonal passives, a tentative suggestion might be that events designated by these verbs are considered not to happen to people in general; but it suffices to say for the purpose of this study that the conventional meanings of these verbs might at best concern events that happen to specific individuals or entities (cf. section 4.2).

(37) Verbs forming impersonal passives:

aka 'drive', berjast 'fight', dvelja 'stay', elska 'love', falla 'fall', fljúga 'fly', flytja 'move', fremja sjálfsmoro 'commit suicide', dansa 'dance', fara 'go, ganga 'walk', geispa 'yawn', giftast 'marry', gróa 'grow', halda 'think, consider', hjálpa 'help', hlaupa 'run', horfa á 'look at', hlusta (á) 'listen to', hrópa 'cry', hugsa 'think', hvilast 'rest', kenna 'teach', koma 'come, arrive', koma fram 'appear, come into being', lcera 'learn', minnast 'recall', óska 'wish', sakna 'miss', sigla 'sail', sitja 'sit', sjá 'see', skjálfa 'shiver', snökta 'sob', synda 'swim', syngja 'sing', vaka 'be awake', vita 'know', yfirvega 'think over', pekkja 'know', pvo 'wash', ...

(38) Verbs not forming impersonal passives:

birtast 'appear', blotna 'become wet', bogra 'stoop, crawl', brotna 'break', detta 'fall', deyja 'die', deyfa 'make dim', dofna 'become weak', dropa 'drop, leak', heyra 'hear', hverfa 'disappear', kafna 'suffocate', leka 'leak', lika 'like', lykta 'smell', neita 'refuse', ruilla 'roll', sofna 'fall asleep', sökkva 'sink', titra 'shiver', vakna 'become awake', velta 'tumble', ...

\subsection{Indefiniteness}

In the previous section I claimed that Icelandic impersonal passives express generic events. This section provides further evidence for its validity by referring to the adverbial expression sér meðvitandi 'consciously, knowingly' which is claimed to express definiteness. ${ }^{10}$

\footnotetext{
10 The expression sér meorvitandi is a compound expression of a dative reflexive pronoun sér for third person and an adjective meðvitandi, a derived form of the noun meðvitund 'consciousness', arising originally from the verb vita 'know' to which the preposition med 'with' is concatenated.
} 
Let us first consider the behaviour of this adverbial expression. The reflexive sér usually means 'for the sake of' or 'for the advantage of' and is used to supplement this semantic element to verbs that appear as transitive. ${ }^{11}$ This is the reason why (39)b is ungrammatical. Consider (39)c in which the appearance of sér stresses Magga's intentional action. Therefore, (39)e is ungrammatical because an inanimate entity such as a ship cannot have an intention. Thus, (39)a differs from (39)c in that Magga in (39)a sank independently of her will. Although sér has something to do with intention or will, this specific meaning fades away when it occurs in the combination of meðvitandi, as in (39)f.

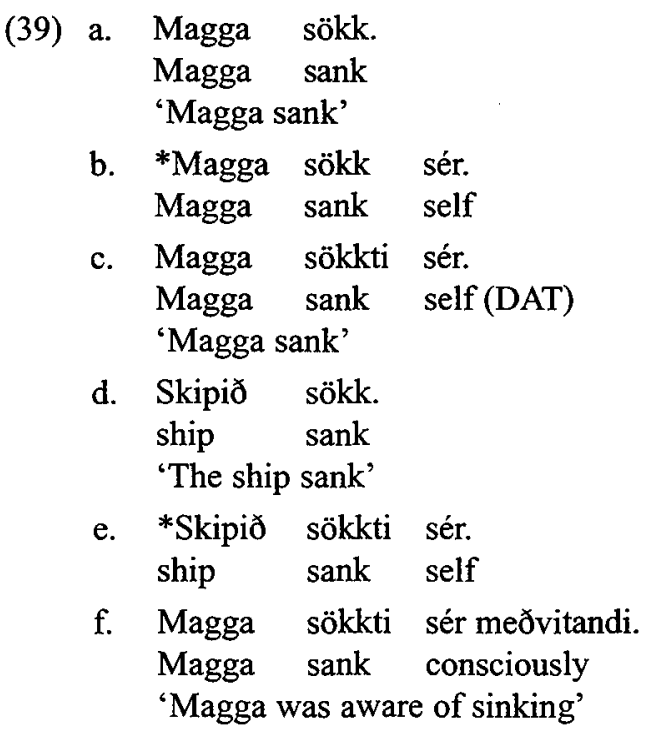

Sér meðvitandi can also co-occur with verbs, normally not taking sér on their own. As demonstrated by the verb detta 'fall' in (40), the element 'for the sake of' is not required by detta. Together with (39)f, sér in sér meðvitandi is not exactly the same thing as a normal reflexive sér; hence, it might be fair to say that this complex expression is semantically a unified construct that independently expresses the semantics of consciousness or awareness.

(40) a. *Hans datt sér.

Hans fell self

b. Hans datt sér meðvitandi.

Hans fell consciously

'Hans was aware of falling'

${ }^{11}$ Certain verbs such as sleppa 'escape, release', sökkva 'sink', stökkva 'jump', smella 'snap, bang', velta 'roll' have two distinct past tense forms. As seen in (39), the verb sökkva has sökk for intransitive and sökkti for transitive verbs. 
My contention is that the behaviour of sér meðvitandi accounts for the applicability of Icelandic impersonal passives that express genericity. It is a well-known fact that the meaning of genericity is often conveyed by indefinite expressions (e.g. Krifka et al 1995). For instance, bare noun phrases in Icelandic are often responsible for the expression of generic sentences.

Bjórar byggja stíflur.

beavers build dams

'Beavers build dams'

Consider the contrasting examples in (42) and (43) where verbs that form an impersonal passive are not compatible with sér meðvitandi, while this adverbial is felicitous when the verb does not form an impersonal passive. This is somewhat surprising at first sight since both hlaupa 'run' and rúlla 'roll' are semantically close to each other, in the sense that they encode a motion component.

(42) a. pað er hlaupið.

it is run

'People are running'

b. *Magnús hleypur sér meðvitandi.

Magnús runs consciously

(43) a. *๖að̃ er rúllaơ.

It is rolled

'People are rolling'

b. Magnús rúllar sér meơvitandi.

Magnús rolls consciously

In comparison, as illustrated in (44) and (45), these verbs uniformly accept adverbials such as viljandi 'intentionally' or af ásettu ráð $i$ 'intentionally' (see also section 2.4 ), indicating that the component of volition does not provide an explanation of why (42) and (43) behave differently.

(44) Magnús hleypur viljandi/af ásettu ráo.

Magnús runs intentionally

(45) Magnús rúllar viljandi/af ásettu ráō.

Magnús rolls intentionally

Consider the examples in (46) and (47) where definite and indefinite interpretations neatly distinguish sér meðvitandi from viljandi and af ásettu ráði; the former co-occurs with the definite noun phrase, while the latter can appear irrespective of the definiteness distinction ((46)a and (47)a)). An interesting fact that further confirms our observation is that relative clauses serve to impart a definite property, that is, sér meðvitan- 
$d i$ is acceptable when folk 'people' is a head noun modified by the relative clause headed by sem 'who', as shown in (47)b.

(46) Indefinite:

$\begin{array}{llll}\text { a. } & \text { *Fólk } & \text { syngur } & \text { sér meðvitandi. } \\ & \text { People } & \text { sing } & \text { consciously } \\ \text { b. } & \text { Fólk } & \text { syngur } & \text { viljandi/ af ásettu ráði } \\ & \begin{array}{l}\text { People } \\ \text { sing }\end{array} & \text { intentionally }\end{array}$

(47) Definite:
a. Fólkið syngur sér meðvitandi.
'People.the sing consciously'
b. Fólk, sem er rauðklætt, syngur sér meðvitandi.
People who are dressed in red sing consciously
'People who are dressed in red sing consciously'
c. Fólkiðð syngur viljandi/ af ásettu ráði
people.the sing intentionally
'People sing intentionally'

The distinction with respect to the definite or indefinite properties goes essentially along with our characterisation of the impersonal passive construction. More precisely, the reason sér meðvitandi is infelicitous with verbs that form an impersonal passive, as shown in (42), is clearly that the definiteness encoded in this adverbial expression does not match the semantics of the base verb which does not count as definite. Following this, the fact that the verb rilla 'roll' does not license an impersonal passive (43) is due to the property of definiteness associated with this type of verbs, and, of course, this semantic component does not meet the generic characterisation of the impersonal passive.

A question arises. How can we distinguish between definite and indefinite meanings encoded in verbs? One solution might be to regard this distinction as purely linguistic. In other words, the assignment of definite and indefinite meanings to events denoted by verb forms is to be taken as 'arbitrary' (Saussure 1916 [1983]). It goes without saying that, it is indeed not easy, on cognitive grounds, to explain why the event expressed by hlaupa 'run' is indefinite, while that of rúlla 'roll' is definite, insofar as we can say that in both cases one can, in principle, be aware of doing a designated activity. It might suffice to say, however, that, due to arbitrariness of language, this given distinction is made possible when native speakers of Icelandic are in agreement with it when they make an utterance.

Thus, what is relevant in our ongoing discussion is to identify the fact that the constructional meaning of genericity is affecting, or imposing constraints upon, the behav- 
iour of verbs in Icelandic. Accordingly, the present discussion not only justifies our intuition that there is a linguistic construct that might adequately be dubbed 'the Icelandic impersonal passive construction' but also explains why semantic factors proposed on the basis of other languages such as Dutch do not hold for Icelandic.

\section{Summary and Remaining Problems}

The discussion in the preceding sections indicates that there are fine-grained semantic factors that systematically take part in the formation of Icelandic impersonal passives. The existence of these factors has also been shown, if not in any direct manner, to be unmotivated by the unergative/unaccusative distinction. We then claimed that one crucial factor that licenses the construction is genericity encoded in it. By showing that the adverbial expression sér medvitandi 'intentionally, knowingly', which picks out the definiteness component, is infelicitous with passivisable verbs, we provided good evidence that impersonal passives in Icelandic express generic events that characterise or summarise what people generally do. This observation led us to the fact that expressions such as viljandi or af ásettu rádi, which are taken as expressing volition, are insensitive to (in)definiteness, and this explains why Icelandic differs from languages such as Dutch (Perlmutter 1978; Zaenen 1993) where volition is considered to be a relevant factor. In this respect, it might be correct to say that finegrained semantics underlying the formation of Icelandic impersonal passives is, as far as we can surmise, largely language-specific. We have also drawn attention to the fact that classifications such as activity or stative predicates can hardly count as semantic primitives, as opposed to Van Valin (1991); our discussion made it clear that the notion of activity is obviously still coarse-grained and ambiguous. The inappropriateness of his analysis lies crucially in his failure to observe the very fact that the Icelandic impersonal passive encodes genericity.

Researchers working within the Construction Grammar framework state that there are grammatical constructions that exist independently of verbs which instantiate them. This idea appeals to our Icelandic data, while we still feel that the description of constructions in terms of the argument structure of a predicate such as X CAUSES $Y$ TO RECEIVE $Z$, along the lines proposed in Goldberg $(1995,1998)$, might not count as an appropriate representation to our present finding. In other words, constructional meanings are, in our terms, built more on our interaction with extralinguistic components, and these components clearly extend beyond the number of arguments and type of predicates encoded. In this regard, the proposal in Kay and Fillmore (1999) might provide us a sound testing ground for further research on the nature of grammatical constructions.

Although I trust that the present proposal explains a great deal of the relevant facts of the Icelandic impersonal passive, there are still facts, as given below, that might not be explained purely semantically nor along the lines proposed above. I believe that if we solve, or gain insight into, these problems, a unified account of impersonal passives 
in Icelandic will certainly be arrived at, and, concurrently, we will make a contribution to our real understanding of the nature of natural language.

(48)

(I) All verbs which take a reflexive sig 'self' (e.g. baða sig 'take a bath') do not form impersonal passives.

(II) There are verbs such as deyja 'die', spretta 'grow', vaxa 'grow' which are, when appearing with vera 'be', ambiguous and open to generic and resultative interpretations depending on the given context.

(III) There are a small set of verbs such as flytja 'move', borða 'eat', whose behaviour is not consistent with the present proposal; they are compatible with sér medvitandi 'consciously, knowingly', while forming an impersonal passive.

(IV) Verbs such as geispa 'yawn', sitja 'sit', skilja 'understand', snökta 'sob', vinka 'wave', when they form impersonal passives, do not allow an overt expression of an af phrase with a generic NP (e.g. af fólkinu 'by people').

\section{References}

Comrie, Bernd. 1977. In Defense of Spontaneous Demotion: The Impersonal Passive. In Cole, P, J. M. Sadock (eds.), Syntax and Semantics, vol. 8. Grammatical Relations. San Diego: Academic Press.

DowTY, David. 1991. Thematic Proto-Roles and Argument Selection. Language, 67 (3), 547-619.

GoldBerg, Adele. E. 1995. A Construction Grammar Approach to Argument Structure. Chicago: The University of Chicago Press.

GoldBerg, Adele E. 1998. Patterns of Experience in Patterns of Language. In Tomasello, M. (ed.), The New Psychology of Language, 203-220. New Jersey/London: Lawrence Erlbaum Associates, Publishers.

Kathol, Andreas. 1994. Passives without Lexical Rules. In Nerbonne, J., K. Netter, and C. Pollard, (eds.), German In Head Driven Phrase Structure Grammar, 237-272. Stanford, Calif.: CSLI Publications.

KAY, Paul and Charles FILlmoRE. 1999. Grammatical Constructions and Linguistic Generalizations: The What's $\mathrm{X}$ doing Y? Construction. Language, 75(1), 1-33.

Klaman, M. H. 1991. Grammatical Voice. Cambridge: Cambridge University Press.

Krifka, Manfred, Francis J. Pelletier, Gregory N. Carlson, Alice ter Meulen, Godehard Link, and Gennaro ChIERCHIA. 1995. Genericity: An Introduction. In Carlson, Gregory N. and Francis J. Pelletier (eds.), The Generic Book, 1-124. Chicago and London: The University of Chicago Press.

LEVIN, Beth. and M. RAPPAPORT. 1989. An Approach to Unaccusative Mismatches. Proceedings of NELS, 314329. Amherst: University of Massachusetts.

Perlmutrer, David. 1978. Impersonal Passives and the Unaccusative Hypothesis. Jaeger, J. J. et al. (eds.), Proceedings of the 4th Annual Meeting of the Berkeley Linguistics Society, 157-189. California: University of California, Berkeley.

POLLARD, Carl. 1994. Toward a Unified Account of Passive in German. In Nerbonne, J., K. Netter, and C. Pollard, (eds.), German In Head-Driven Phrase Structure Grammar, 273-296. Stanford, Calif.: CSLI Publications.

SAUSSURE, Ferdinand de. 1916 [1983]. Course in General Linguistics. ed. by Charles Bally and Albert Sechehaye in collaboration with Albert Reidlinger. Translated from the French by Wade Baskin. London: Duck-worth.

SHIBATANI, Masayoshi. 1985. Passives and Related Constructions: A Prototype Analysis. Language, 61(4): 821-848.

SMITH, Henry. 1993. Linking Changes in Icelandic. Historical Linguistics. Papers from the 9th International Conference on Historical Linguistics, 467-484. Amsterdam/Philadelphia: John Benjamins Publishing Company.

VAN VALIN, Robert. Jr. 1991. Another Look at Icelandic Case Marking and Grammatical Relations. Natural Language and Linguistic Theory 9: 145-194. 
YAMAGUCHI, Toshiko. (2000). Icelandic Auxiliaries Hafa and Vera. A Semantic Account. In Alan K. Melby and Arle R. Lommel (eds.), LACUS Forum XXVI, 305-320. Fullerton, Calif.: The Linguistic Association of Canada and United States.

ZAENEN, Annie. 1993. Unaccusativity in Dutch: Integrating Syntax and Lexical Semantics. In Pustejovsky, J. (ed.), Semantics and the Lexicon, 129-161. Dordrecht: Kluwer.

ZAENEN, Annie. and Joan MALING. 1990. Unaccusative, Passive and Quirky Case. In Maling, J. and A. Zaenen (eds.), Syntax and Semantics. Modern Icelandic Syntax, vol. 24, 137-152. San Diego: Academic Press.

\section{Povzetek}

\section{BREZOSEBNI TRPNIK V ISLANDŠČINI}

V prispevku se utemeljuje misel, da islandski brezosebni trpnik izraža generična glagolska dejanja, v katerih delujejo ljudje. Dokaz so diagnostični testi, ki kažejo, da so brezosebni trpni stavki združljivi samo $z$ izrazi, ki se ne nanašajo na posamična glagolska dejanja. Tako so testi neuspešni $\mathrm{s}$ prislovnim določilom sér meðvitandi 'zavestno, zavedajoč se', o katerem se navaja, da izraža določnost. V nadaljevanju avtorica odkloni pojem dejavnosti kot činitelja, ki da sproža islandski brezosebni trpnik (Van Vanlin 1991), ker je ta pojem preohlapen, da bi se mogle z njim izvesti kake posplošitve. Avtorica vidi v generičnosti lastnost stavkov, ti pa so idiomatksa povezava med obliko in pomenom. To misel šteje za obetavno, vendar prepušč prihodnjim raziskavam, kako bodo povezale obravnavane pojave z zgradbenostjo (prim. Goldberg 1995, Kay in Fillmore 1999). 